\title{
Dendrogeomorphological study of glacier fluctuations in the Italian Alps during the Little Ice Age
}

\author{
Manuela Pelfini \\ Dipartimento di Scienze dell'Ambiente e del Territorio, Università di Milano, I-20126 Milano, Italy
}

\begin{abstract}
In the Italian Alps, the maximum advance of the Holocene usually coincided with the Little Ice Age (LIA), which reached a climax for most glaciers during the first two decades of the 19th century. Moraines deposited during the peak of the LIA usually obliterated glacial deposits from previous advances. Using dendrogeomorphology, it is possible to date glacier advances before the LIA peak. In the central Italian Alps, it was possible to pinpoint an advance of Ghiacciaio del Madaccio, which took place in the first two decades of the 17 th century. With dendrogeomorphology, it is also possible to reconstruct in detail the behaviour of glaciers during the Little Ice Age climax. Trees growing on the margin of glacier tongues may have suffered damage, recognizable by the presence of wood scars and the formation of particularly thin rings; their dating allows both ice advances and retreats to be dated. This is the case for Ghiacciaio Grande di Verra in the western Italian Alps; owing to the rapid decrease of the tree ring widths, it is possible to recognize climate changes responsible for both lower wood production and, sometimes, subsequent glacier advances, although the latter take place with a certain delay. For Ghiacciaio del Lys in the western Italian Alps, a response time of five years was determined.
\end{abstract}

\section{INTRODUCTION}

In the Alps, recently deglaciated proglacial areas have nested moraine systems that are either bare or poorly covered by vegetation. Landscape features are of paramount importance in reconstructing past glacier behaviour and, traditionally, the focus has almost exclusively been on the glacial landforms and deposits. Among landscape elements, not only glacial deposits should be considered, but also trees and other kinds of vegetation, since they allow a proper interpretation of both the present landscape and past glacial dynamics. In the Italian Alps, the maximum Holocene advance usually coincided with the Little Ice Age (LIA), which reached a climax for most glaciers during the first two decades of the 19th century (Pelfini, 1992; Pelfini and Smiraglia, 1992; Orombelli and Pelfini, 1993; Orombelli and Mason, 1997). The reconstruction of glacier advances preceding the LIA climax is rather problematic. The moraines deposited during the LIA peak have usually obliterated the glacial deposits resulting from previous advances, apart from rare cases in which some remnants of lateral moraines have been preserved (Pelfini, 1992). Even more difficult is the reconstruction of the detailed history of advance and retreat phases when glaciological measurements and abundant historical records are not available. Nevertheless, the trees growing near glacier fronts allow the behaviour of Alpine glaciers during past centuries to be reconstructed. The ring width is strictly correlated with the climate. Decreasing ring width is observable as negative peaks or trends in dendrochronological curves. This evidence from the tree chronologies allows climate changes responsible for lower wood production, and sometimes subsequent glacier advances, to be recognized although the latter occur with a certain delay (Fritts, 1976; Schweingruber, 1988; Schwein- gruber and others, 1990). Following a general change in temperature and precipitation levels, glaciers respond first by changes in their mass balances and equilibrium-line altitudes, then by frontal advance or retreat. This delay is the response time (Pelfini and others, 1997).

Moreover, the trees growing beside glacier tongues may have suffered damage recognizable in both the presence of wood scars and the formation of particularly thin rings. Their dating, simply carried out by counting the rings on living trees or by cross-dating dead tree trunks, allows the corresponding glacier advance to be dated indirectly. Since very thin rings continue to be produced as long as ice is in contact with trees, it is possible to date both the ice advance and its retreat, thus identifying the position of the glacier front at specific dates.

Several studies have been carried out on the Holocene fluctuations of Alpine glaciers (Pelfini, 1988; Pelfini, 1992; Pelfini, 1995; Orombelli and Mason, 1997). In the Italian Alps, some 30 glaciers have been studied in detail and research has concentrated on the most glacierized sectors; the Monte Bianco, Monte Rosa, Bernina, Ortles-Cevedale and Adamello-Presanella mountain groups (Fig. 1). The most ancient phases are poorly documented, whereas there is abundant data for the period ranging from the LIA maximum to the present day. There is only good evidence for the chronology of LIA phases in Italy from the mid-18th century onwards, even if some evidence remains of previous advances. For example, at Ghiacciaio del Miage in Valle d'Aosta, a tree stump buried by a moraine records an ice advance that occurred in the 17th century (1639) of the same magnitude as the maximum Holocene expansion (Aeschlimann, 1983). When Ghiacciaio del Rutor was advanced, it dammed a watercourse. Small ice-volume decreases caused various floods; the one dated 1284 seems to indicate an early advance 


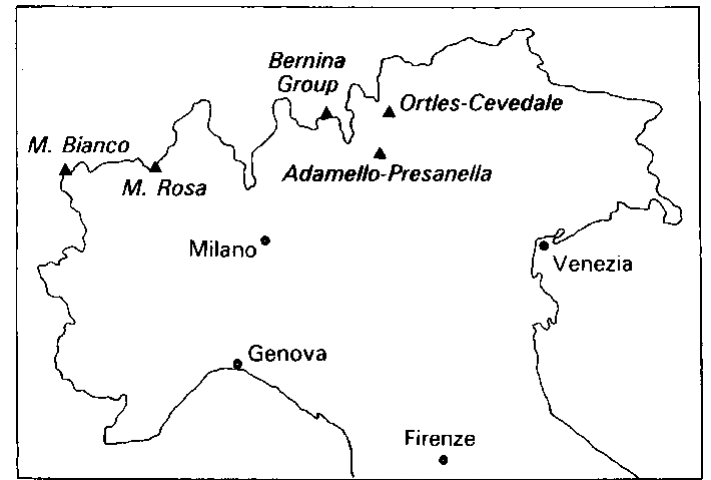

Fig. 1. The more than 30 glaciers studied in detail in the Italian Alps are concentrated on the most glaciated sectors of the mountain groups of Mont Blanc, Monte Rosa, Bernina, OrtlesCevedale and Adamello-Presanella.

phase of the LIA during the 13th century (Aeschlimann, 1983). Successive variations of the front in a rather advanced position have been connected to floods in 1594-97, 1630, 1640, 1646, 1679 and 1751 (Sacco, 1917). For some glaciers, such as the Pré de Bar and Miage in Valle d'Aosta, lichenometric investigations have led to the conclusion that the LIA peak was attained during the 18th century. With other glaciers of the Ortles-Cevedale group (Ghiacciaio del Forni, Col di Lamare glacier), lichenometric investigations carried out on the remnants of lateral moraines, distal to those deposited during the LIA peak, have identified advance phases ascribable to the 17 th and 18th centuries (Pelfini, 1988, 1992). In these periods, the glaciers had a wider, but less advanced, tongue than during the peak LIA advance.

\section{DENDROCHRONOLOGY OF PRE-LIA ADVANGES}

In most cases, there is no geomorphological evidence in the Italian Alps for advances preceding the LIA maximum, since this destroyed previously deposited moraines. The ages of living trees give a minimum age for the moraines. However, in some cases, dendrochronology is very helpful: the presence of old living trees, on top of lateral or lateral-terminal moraines, and the analysis of mean dendrochronological curves for the same area, sometimes permit the reconstruction of glacial events even when they preceded the LIA peak. Trees living near glaciers record the climatic variations (Schweingruber, 1988). When the climate cools, the tree rings became thinner, the chronologies show negative peaks and the glaciers may advance.

In the Madaccio valley, on the northern slope of the Ortles-Cevedale group in the Italian South Tyrol Alps, after a geomorphological survey and the mapping of moraines, more than 300 tree-core samples were collected and analyzed. The Ghiacciaio del Madaccio, over time, has changed the shape and position of its tongue. During the 17 th century, the glacier advanced, occupying the eastern portion of the present proglacial plain; whereas in more recent times, the front has remained only in the midle of the valley trough, although it has reached lower altitudes. For this reason, a terminal moraine of the eastern lobe, preceding the climax of the LIA, was preserved. A larch growing here gives a minimum age of 1624 for the moraine. A larch still living on the great eastern lateral moraine, which germinated in 1538, shows a decline in growth rate between 1597 and 1612, with two particularly pro- nounced minima in 1605 and 1608. This shows that an advance took place during the first two decades of the 17 th century. This is the first well-documented advance ascribable to the LIA for the Ghiacciaio del Madaccio (Fig. 2).

The analysis of dendrochronological curves and chronologies cannot provide information on glacier advance phases directly; it can only pinpoint the presence of intervals characterized by vegetational crisis, owing to periods of cooling weather. Phases of glacier advance are the response of glaciers to periods of worsening climate, although movement at their termini takes place with a certain delay (Paterson, 1994). On the other hand, cold intervals are recorded immediately by trees, which are a natural archive of paleoclimatic data (Schweingruber, 1988; Pelfini and Orombelli, 1997). However, the contrary is not always true; periods of worsening climate, that show as negative peaks in dendrochronological curves, are not always followed by phases of glacier advance. An example is offered by the cold period at the end of the 17 th century which, although characterized by low temperatures, did not cause substantial and general advances of Alpine glaciers, apart from some exceptions such as the Mont Blanc group (Ladurie, 1971; Grove, 1988). Indeed, during the 16871704 period, scarce winter precipitation hindered any noticeable increase in mass balance (Pfister, 1994).

However, the analysis of dendrochronological curves, combined with other types of information, do allow advances of Alpine glaciers to be dated, as shown by the Ghiacciaio del Madaccio. The advance recognized for this glacier in the first two decades of the 17th century is one of the several advance phases documented in the Alps from the end of the 16 th century and the beginning of the $17 \mathrm{th}$. For example, noticeable ice advances were described for the Grindelwaldgletscher (1588), Allalingletscher (1589), Mont Durand (1599), Mer de Glace (1600) and Vernagtferner (1616) (Ladurie, 1971). On Mont Blanc, the Glacier d'Argentière started to advance in 1580, and the Glacier Des Bois reached its maximum expansion between 1599 and 1600; whereas from 1605-10 it remained stationary (Grove, 1988). Therefore, in the mid-17th century, an advance phase can be inferred for the Ghiacciaio del Madaccio. Ladurie (1971) recognized a phase of glacial advance for this time interval, which is also supported by historical records describing the advances of Glacier Des Bossons (1641-43), Glacier Des Bois (1642), Ghiacciaio del Rutor (1640-46) and Aletschgletscher (1653). The Tour and Argentière glaciers went through an advance phase in the years 1641-43 (Grove, 1988).

At the end of the 17 th century, a critical interval started for trees in the Madaccio valley, which ended only after the LIA maximum. From the mean curve for larches, it can be seen that the 1670-1821 interval, which is characterized by reduced vegetation growth, may be subdivided into three main phases (Fig. 3). The first phase stretched from about 1670 to 1720 , the second from mid-1700 to 1785 , which was particularly cold between 1770 and 1782, and the third one from 1792 to 1821 . During the 1670-1790 interval, a mass destruction of trees occurred in the Madaccio proglacial area, as shown by the dates of the death of tree trunks buried by glacial and glaciofluvial deposits (1678, 1751, 1754 and 1790). The peak of the Madaccio advance took place around 1770. A still-living spruce was found at the foot of the moraine's outer slope. The germination of this spruce dates back to at least 1790. By taking into account the time necessary for recolonization, the moraine could have been completely abandoned since at least 1770. Nevertheless, the front of the glacier 


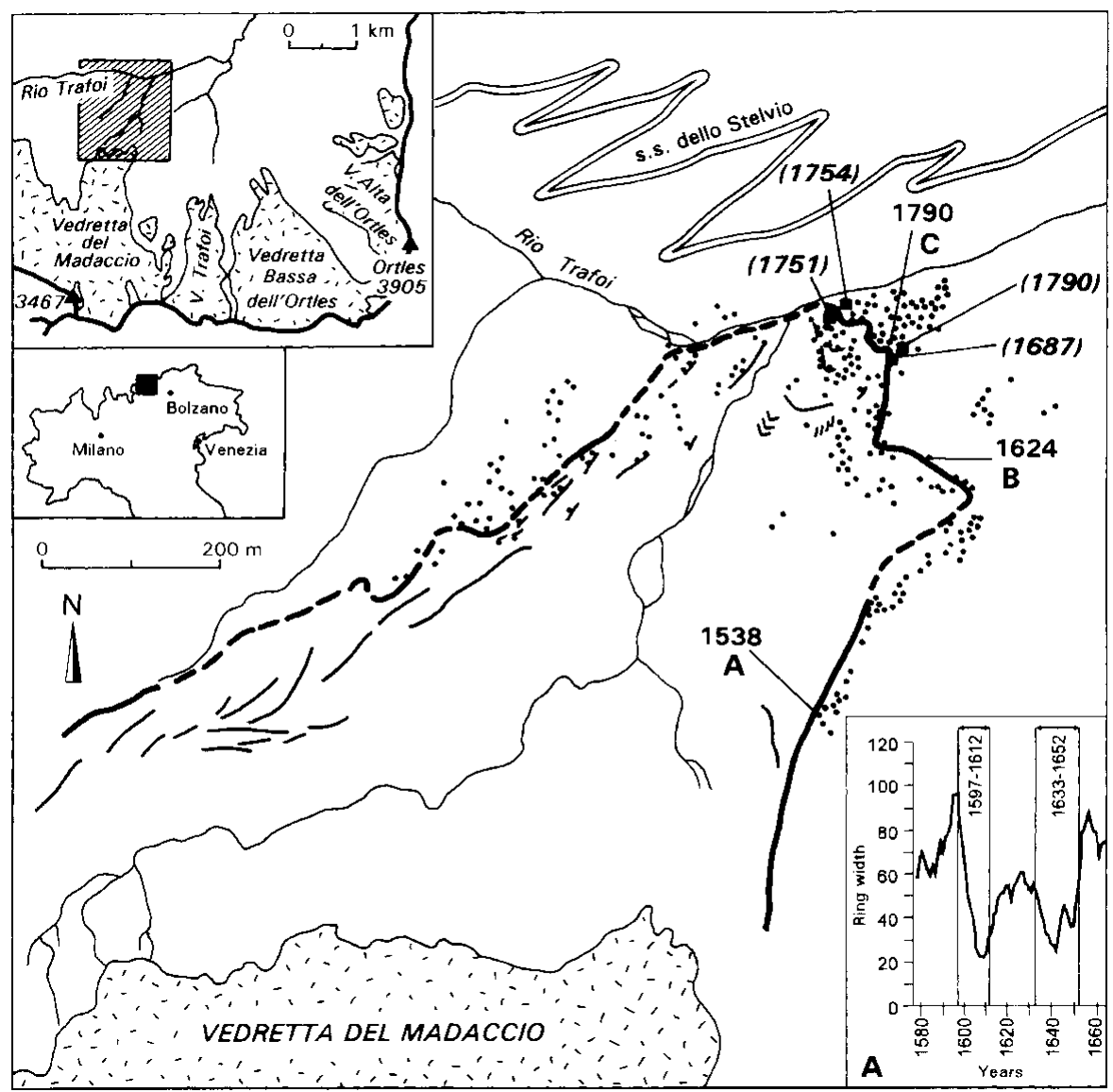

Fig. 2. Ghiacciaio del Madaccio proglacial area. Bold lines show maximum LIA advance. Thinner lines correspond to moraines deposited during minor advances. Black points represent all trees sampled to obtain dendrochronological curves for Larix decidua, Pinus cembra and Picea abies. "A" is site of a larch growing on the edge of the eastern lateral moraine. Part of its dendrochronological curve shows a strong decrease in growth from 1579-1612. "B" is site of a larch growing on the terminal moraine of the eastern lobe; the tree germinated in 1624. It is therefore possible to identify an advance of the Ghiacciaio del Madaccio in the first two decades of the 17th century. Numbers in brackets correspond to year of death of the half-buried trunks.

remained in a rather advanced position until the end of the 18th century, with possible minor advances in the last decade of the century.

The 1750-80 period was characterized by an expansion of most Alpine glaciers (Grove, 1988). Dated advances go back to 1748 for Vernagtferner, to $1748-51$ for Ghiacciaio del Rutor, to $1756-77$ for Grindelwaldgletscher, and to 1778 for Rhonegletscher. The following were also advancing in this period: Glacier de Triolèt in 1781; Ghiacciaio della Brenva, which reached the southern flank of Val Veni in 1776; the Mer de Glace from 1777-84 when a retreat phase began; Glacier d'Argentière from 1778-80; and Grindelwaldgletscher in 1778 (Grove, 1988).

In this period the tongue of Ghiacciaio Grande di Verra, inValle d'Aosta, advanced considerably causing the first damming phase of Lago Bleu (unpublished report by M. Pelfini).

Dendrochronological curves of the Madaccio valley show that an attenuation of the cold phase took place at the end of the 18th century. A marked worsening definitely occurred from the beginning of the 19th century; the maximum of the advance which followed this cold phase was reached in 182021 , which is also supported by historical evidence.

\section{PHASES OF THE PRE-LIA GLIMAX}

During the advance stages of the LIA, Ghiacciaio Grande di
Verra, in Valle d'Ayas, western Italian Alps, partly destroyed the larch forest in the upper valley. Only the trees growing along the margin of the glacier's tongue survived, although damaged. At the same time, the advance dammed a small watercourse creating Lago Blu, where some dead larch trees were found, and deposited two large lateral moraines. The middle portion of the western lateral moraine makes up the outlet sill of Lago Blu and stretches as far as the root system of some living larch trees. The tree cover of the upper Valle d'Ayas has recorded both the intervals of climate worsening responsible for the glacier's frontal advance, and the direct damage caused by contact with ice, thus allowing detailed analyses of the glacier's frontal movements and of its advance and recession velocity. Ghiacciaio Grande di Verra was the first example in Italy for which dendrogeomorphological investigations allowed not only reconstruction of the advance phases of the glacier front, but also its recession phases, for which no other evidence remained. 120 tree-core samples were analyzed. Ten were from larches close to the lateral moraine and directly damaged by the glacier ice; four were from dead larches located in the lake and still in a vertical position; the other samples were from larches on the slope and in the proglacial area. Each tree near the lateral moraine recorded the moment of "arrival" of the glacier and the following years by producing a typical sequence of narrow growth rings. Once dated, the sequence allowed the precise position of the glacier front for a particular year to 


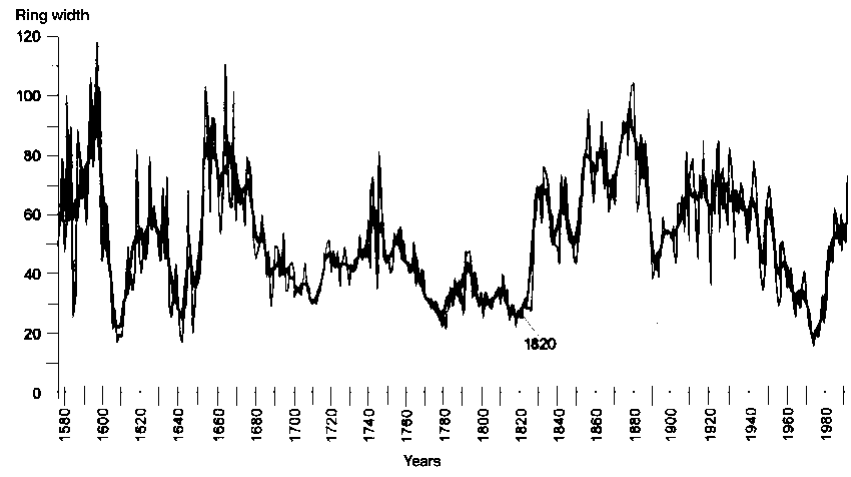

Fig.3. Mean dendrochronological curve for Larix decidua in the Madaccio valley.

be reconstructed. Since the trees are distributed all along the western lateral moraine, from the lake sill as far as a bridge over the stream ( $*$ in Fig. 4 ), it is possible to reconstruct the patterns of advances up to the LIA maximum, since the typical sequence is progressively shifted forward in time as one proceeds downstream. When the glacier started to retreat, the trees began to recover first downstream and then more and more upstream. Analyzing the samples from upstream to downstream, the following periods were identified: (1) the year when growth reduction started to take place, which corresponds to a phase of significant climate worsening; and (2) the year when direct contact with the ice took place, which was responsible for a considerable decrease in annual wood production. By analyzing the same samples from downstream to upstream, the year of ice retreat and subsequent climatic improvement could be reconstructed (Fig. 4).

The mean chronologies for the Valle d'Ayas underline that there was a phase of considerable thinning of the growth rings, already in the mid-18th century, following a positive phase culminating in 1739. This climatic cooling intensified until 1790, with significant peaks in 1785-86 and 1795. Starting from the mid-18th century, Ghiacciaio Grande di Verra began to expand beyond the lake barrier. The advance, which led to the maximum Holocene expansion of this glacier, went through two phases:

(a) From the mid-18th century onwards, considerable glacier expansion started the damming phase of the watercourse and consequently the formation of Lago Blu. The first impulse at the end of the 18th century was very marked and the glacier advanced with a velocity considerably greater than the phases of the LIA climax.

(b) The expansion of Ghiacciaio Grande di Verra slowed down at the beginning of the 19th century (1802-1808).

(c) The second positive impulse, which led to the deposition of the outermost moraine, was less pronounced and the glacier advanced slower.

At the terminus, a living tree marks the contact with the glacier front, which occurred in 1819 and lasted until 1821, when the glacier probably started to abandon the terminal moraine near the bridge over the Verra river. The moraine must have been abandoned from 1822, as shown by the subsequent sharp renewal of the growth rate. Also, the arc-shaped trunk witnesses the pressure that was probably exerted by the glacier's front. The outermost terminal moraine was dated using the ages of the living trees growing on the glacial de-

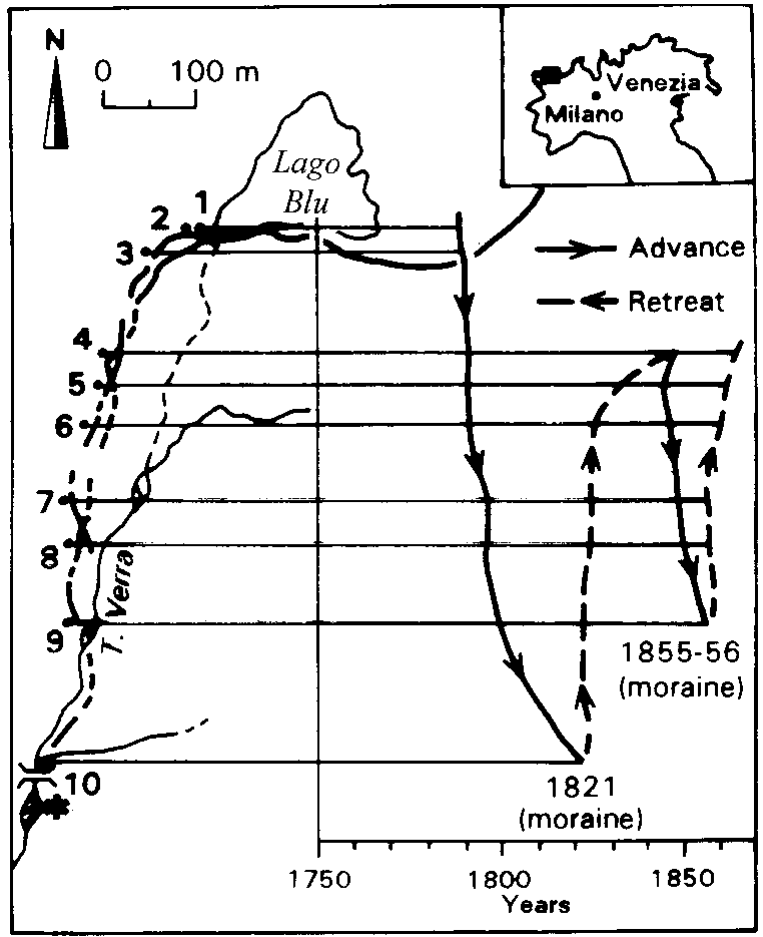

Fig. 4. Ghiacciaio Grande di Verra fluctuations during the LIA advance. 1-9 corresponds to trees damaged by the glacier during its advance.

posit. The age of the trees immediately inside the outermost terminal moraine indicates the area must have been abandoned by the glacier from at least the mid-19th century.

The subsequent period of reduction in wood production around the mid-19th century records the second advance of Ghiacciaio Grande di Verra, which led to the deposition of an inner moraine in 1856 (Strada, 1987).

\section{RESPONSE TIME OF ALPINE VALLEY GLAGIERS}

Many researchers have dealt with glacier response time (Haeberli and others, 1994; Haeberli, 1996). In Italy, the response time has been estimated using many different methods (Belloni and others, 1985, 1991; Smiraglia, 1986). These methods have generally been based on a linear correlation between the frontal variations and the trend of several climatic parameters, such as temperature and precipitation. Unfortunately, adequate series of meteorological data are not often available. However, many glaciers during the LIA penetrated deep into the forest. Therefore, their dendrochronological curves can be used instead of climatic data series in order to evaluate the response time of the glaciers. Even where glaciers did not reach forested areas during the LIA, and therefore did not directly influence the vegetation growth rate, the trees still recorded the same climatic fluctuations which were responsible for the glacier advances. Therefore, the use of dendrogeomorphological studies are potentially useful instruments for investigations in many situations.

Glaciers respond to a number of climatic parameters, although for Alpine glaciers temperature is the most decisive (Belloni and others, 1985; Smiraglia, 1986). Larches in the Alps are also sensitive to temperature variations. Therefore, the use of a dendrochronological data series as the reference series represents a reliable starting point, since the response time is calculated on the basis of a synthesis of climatic variables, as experienced by the tree itself. 
Since Ghiacciaio del Lys, in the Gressoney valley, a branch of Valle d'Aosta, is one of the most important Italian glaciers that encroached onto the forest during the 19th century, it was chosen to test dendrochronology as a method for calculating the response time of Alpine glaciers. The glacial deposits here consist of four moraine systems. Dendrochronological data from 216 larch cores were subdivided into four groups, corresponding to four morphological units (Fig. 5): one area between the present glacier front and the innermost moraine (M3-M4); two areas between the moraines (M3-M2 and $\mathrm{M} 2-\mathrm{Ml})$; and one area external to the moraine deposited during the LIA climax (Ml).

Four mean dendrochronological curves were obtained and then correlated with the fluctuations of the glacier, as measured by staff of the Comitato Glaciologico Italiano, in order to obtain the response times. Fluctuation data were then correlated with the temperature data series from Lake Gabiet $(2350 \mathrm{~m})$ to evaluate response times with respect to a single climatic parameter (Pelfini and others, 1997). Finally, an attempt was made to correlate the best dendrochronological data series with the temperature data series, to assess whether the vegetation response was simultaneous or not (Pelfini and others, 1997).

Each growth curve of the four morphological units was cross-correlated with the algebraic sum of the yearly frontal variations of Ghiacciaio del Lys (time-distance curve). The trend revealed by the correlation, $r$, was then examined. The minimum in the curve represents the best correlation between the two data series and gives the response time of the Lys glacier, which is a five-year delay (Pelfini and others, 1997).

The annual snout variations of Ghiacciaio del Lys were then correlated with the sums of the summer monthly mean temperature, from the Lake Gabiet meteorological station, in order to evaluate the reliability of the method. The correlations used the sums of the mean monthly temperature for the following months: May-June; May-July; May-August; May-September; June-September; July-September and August-September. For each period considered, the crosscorrelation was also determined using lags of up to 10 years. The early summer monthly means gave a minimum for the lags of 0, 3 and 5 years; the minimum then shifted to 1, 4 and 6 year lags, moving to the later summer monthly means. Therefore, the late-summer months are primarily reflected by snout variations in the following year. By contrast, the influence of late-spring or early-summer is greatest in frontal variations of the current year.

Cross-correlation was also carried out between the fluctuation data and precipitation, as recorded at the Lake Gabiet meteorological station, from 1935-86 (October-May). However, no significant results were obtained. Whilst it is true that the area and variations of a glacier depend both on temperature and precipitation, southern Alpine glaciers are much more sensitive to temperature variations than to fluctuations in precipitation, as found by Belloni and Smiraglia for the Ortles-Cevedale group and for the Bernina group (Belloni and others, 1985; Smiraglia, 1986).

The correlation between dendrochronological series and climatic parameters showed that no delay in the response of the vegetation to temperature changes was recorded. The response time of Ghiacciaio del Lys to climatic variations proved to be approximately five years (Fig. 6).

The results obtained by correlating the mean dendrochronological curves to the frontal variations of Ghiacciaio del Lys were similar to those obtained from correlations

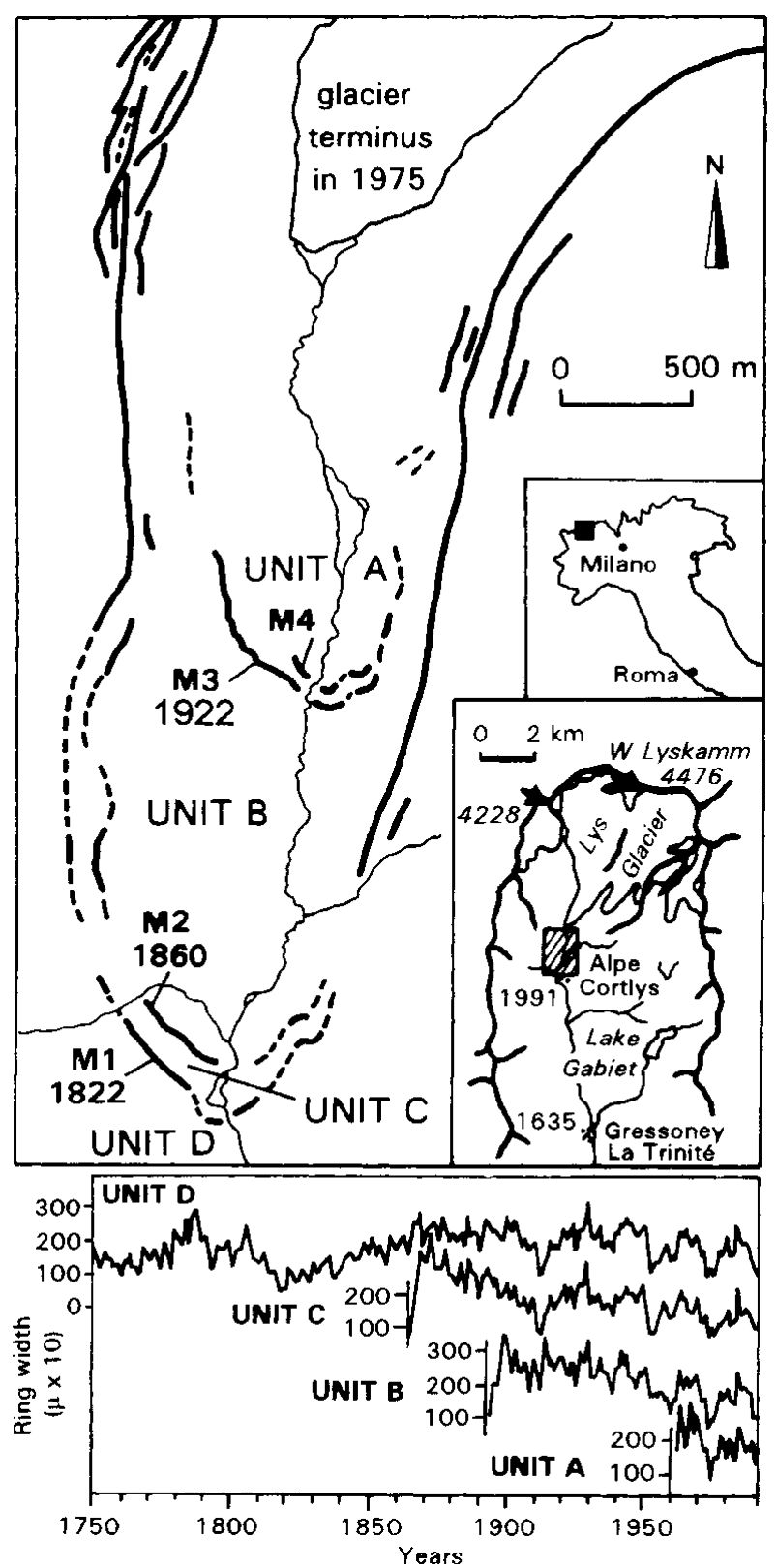

Fig. 5. Ghiacciaio del Lys and its moraines. The groups into which the samples were subdivided are indicated with letters $A, B, C, D$. The curves correspond to the mean dendrochronological curves for different units (modified after Pelfini and others, 1997).

between temperature and the frontal variations. This relationship shows that the dendrochronological method is applicable to studies of glacier response times. The reliability of the method was also confirmed by the fact that there was virtually no delay between climatic input and tree response. The trees most suited for this type of investigation are those situated outside the maximum Holocene advance limit of the glacier. These trees probably react to the climate in the valley head, without being disturbed by the influence of the glacier on the microclimate.

Therefore, the use of a dendrochronological data series as a reference series represents a starting point that is quite reliable because the delay is calculated on the basis of a synthesis of the climatic variables, as registered by the trees themselves. Moreover, this method should be widely applicable as numerous valley glaciers reached wooded areas during the advance phases that started the LIA. Tree records of the events are therefore common. Hence, this 


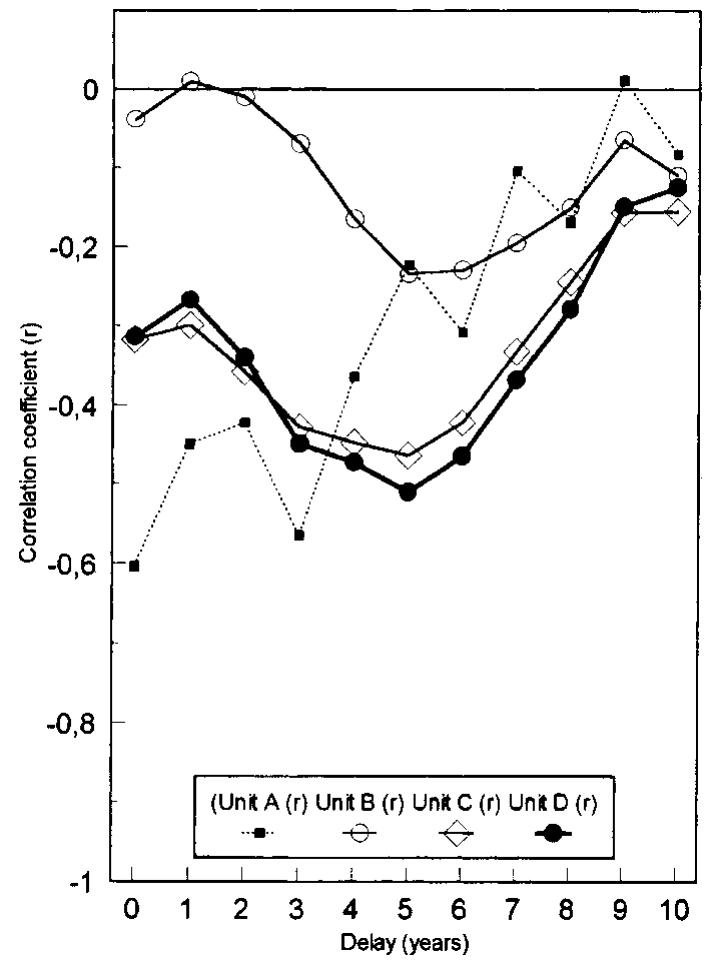

Fig. 6. Correlation coefficient trend for the four different units. The minimum corresponds to a response lag of five years. The best value comes from unit $D$. The trees that record climatic changes best are those located outside the LIA moraine of 1822.

method can be used when adequate series of meteorologial data are not available, as is commonly the case.

\section{CONGLUSIONS}

This paper shows how dendrogeomorphology can be used to reconstruct past glacier behaviour where trees grow next to glaciers. The construction of dendrochronological curves and chronologies, and the determination of the age of trees growing on glacial deposits, can provide precious information that enables the glacier history during the LIA to be reconstructed in detail.

\section{ACKNOWLEDGEMENTS}

The author would like to thank G. Orombelli for his critical revision of the paper and the two referees for their constructive comments. The research was financed by the Murst 1997 programme: "Response of Geomorphological Processes to Environmental Changes" (national coordinator: A. Biancotti; local coordinator: G. Orombelli).

\section{REFERENGES}

Aeschlimann, H. 1983. Zur Gletschergeschichte des italienischen Mont Blanc Gebiets: Val Veni — Val Ferret - Rutor. (Inaug. Diss., Universität Zürich.)

Belloni, S., G. Catasta and C. Smiraglia. 1985. Parametri climatici e variazioni glaciali nel periodo 1950-1982. Geogr. Fís. Din. Quat., 8(2), 97-123.

Belloni, S., M. Pelfini and C. Smiraglia. 1991. Le oscillazioni frontali recenti dei ghiacciai: Alta Valtellina, un approccio metodologico. In Pinna, M., ed. Le variazioni climatiche recenti (1800-1990) e le prospettive per il XI secolo. Rome, Società Geografica Italiana, 167-182.

Fritts, H. C. 1976. Tree rings and climate. London, Academic Press.

Grove, J. M. 1988. The Little Ice Age. London, Methuen \& Co. Ltd.

Haeberli, W. 1996. Glacier fluctuations and climate change detection. Geogr. Fis. Din. Quat., 18(2), 1995, 191-199.

Haeberli, W. and M. Hoelzle. 1995. Application of inventory data for estimating characteristics of and regional climate-change effects on mountain glaciers: a pilot study with the European Alps. Ann. Glaciol., 21, 206-212.

Ladurie, E. L. R. 1971. Time of feast, times of famine: a history of climate since the year 1000. London, George Allen and Unwin.

Orombelli, G. and P. Mason. 1997. Holocene glacier fluctuations in the Italian Alpine region. In Frenzel, B. and others, eds. Glacier fluctuations during the Holocene. Mainz, European Science Foundation, 59-65. (European Palaeoclimate and Man 16.)

Orombelli, G. and M. Pelfini. 1993. I ghiacciai nelle Alpi italiane nell'Olocene e nella Piccola Glaciazione. In Guerrini, C., ed. $3^{\circ}$ Workshop Progetto Strategico Clima Ambiente e Territorio nel Mezzogiorno, 1990, Potenza. Catania, Iolonea Giovanni Litografo, 209-221.

Paterson, W. S. B. 1994. The physics of glaciers. Third edition. Oxford, etc., Elsevier.

Pelfini, M. 1988. Contributo alla conoscenza delle fluttuazioni oloceniche del Ghiacciaio dei Forni (Gruppo Ortles-Cevedale, Sondrio). Nat. Bresciana 24, 237-257.

Pelfini, M. 1992. Le fluttuazioni glaciali oloceniche nel Gruppo Ortles-Cevedale (settore lombardo). (Tesi di Dottorato IV ciclo 1988-1991, Università di Milano.)

Pelfini, M. 1995. Equilibrium line altitude (ELA) variations recorded by Ortles- Cevedale glaciers (Lombardy, Italy) from Little Ice Age to present. Geogr. ̌̌s. Din. Quat., 17(2), 1994, 197-206.

Pelfini, M. and G. Orombelli. 1997. Variazioni recenti dellambiente Alpino registrate nelle serie di anelli di accrescimento delle conifere. Applicazioni della dendrogeomorfologia. Acqua e Aria, 6, 103-110.

Pelfini, M. and C. Smiraglia. 1992. Recent fluctuations of glaciers in Valtellina (Italian Alps) and climatic variations. f. Glaciol., 38(129), 309-313.

Pelfini, M., S. Belloni, G. Rossi and G. Strumia. 1997. Response time of the Lys glacier (Valle d'Aosta). An example of a dendrogeomorphological and environmental study. Geogr. Fis. Din. Quat., 20 (2), 329-338.

Pfister, C. 1994. Spatial patterns of climatic change in Europe A.D. 1675-1715. In Frenzel, B., ed. Climatic trends and anomalies in Europe 1675-1715. Mainz, European Science Foundation, 287-316. (Paläoklimaforschung/Paleoclimatic Research 13, European Palaeoclimate and Man 11.)

Sacco, F. 1917. Il ghiacciaio ed il laghi del Rutor. Boll. Soc. Geol. Ital. 36, 1-36.

Schweingruber, F. H. 1988. Tree rings. Basic and applications of dendrochronology. Dordrecht, etc., Kluwer Academic Publishers.

Schweingruber, F. H., D. Eckstein, F. Serre Bachet and U. O. Brächer. 1990. Identification, presentation and interpretation of event years and pointer years in dendrochronology. Dendrochronologia, 8, 3-39.

Smiraglia, C. 1986. Il ghiacciaio della Ventino (Val Malenco, Alpi Centrali): contributo alla conoscenza dei "tempi di riposta". Geogr. Fís. Din. Quat., 9(1), 49-55.

Strada, E. 1987. Le variazioni del ghiacciaio del Lys dalla "Piccola Glaciazione" ai nostri giorni. Nat. Bresciana 24, 275-288. 